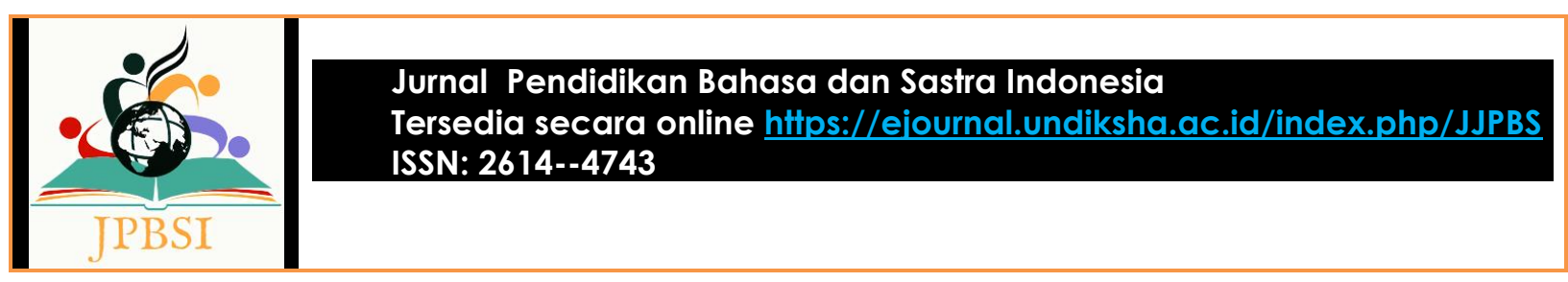

\title{
DAMPAK PEMBELAJARAN JARAK JAUH TERHADAP ASPEK KOGNITIF,AFEKTIF, DAN PSIKOMOTOR BAGI SISWA SEKOLAH MENENGAH ATAS (SMA)
}

\author{
Leni Meilani ${ }^{1}$, Bahja Bastulbar ${ }^{2}$, Wienike Dinar Pratiwi ${ }^{3}$ \\ ${ }^{1,2,3}$ Program Studi Pendidikan Bahasa dan Sastra Indonesia, Universitas Singaperbangsa Karawang \\ Karawang, Jawa Barat, Indonesia
}

\begin{abstract}
Surel:1810631080121@student.unsika.ac.id1',1810631080003@student.unsika.ac.id², wienike.dinar@fkip.unsika.ac.id ${ }^{3}$
\end{abstract}

\begin{tabular}{|c|c|}
\hline \multicolumn{2}{|r|}{ Abstrak } \\
\hline $\begin{array}{l}\text { Kata Kunci: } \\
\text { Pembelajaran Jarak } \\
\text { Jauh; Dampak PJJ; } \\
\text { Kendala PJJ. }\end{array}$ & $\begin{array}{l}\text { Penelitian ini dilakukan untuk mengetahui dampak yang dialami oleh siswa sekolah } \\
\text { menengah atas (SMA) terhadap aspek kognitif, afektif, dan psikomotor selama } \\
\text { pembelajaran jarak jauh atau pembelajaran daring diberlakukan. Selain dampak yang } \\
\text { dirasakan, terdapat pula kendala yang dihadapi oleh siswa menengah atas (SMA) } \\
\text { terhadap penerapan pembelajaran jarak jauh. Rancangan penelitian ini menggunakan } \\
\text { pendekatan deskrptif kualitatif dari hasil kuesioner melalui google form. Kuesioner } \\
\text { diajukan kepada siswa menengah atas mulai dari kelas X, XI, dan dan kelas XII. Jumlah } \\
\text { responden pada penelitian ini sebanyak } 20 \text { responden. Adapun metode yang digunakan } \\
\text { berupa metode kualitatif. Dari hasil penelitian bahwa } 80 \% \text { dari responden mengikuti } \\
\text { Pembelajaran jarah jauh dan } 20 \% \text { responden jarang mengikuti proses pembelajaran jarak } \\
\text { jauh. Hal tersebut dialami oleh siswa baik jurusan IPA maupun IPS. 50\% dari responden } \\
\text { mengalami perubahan terhadap aspek kognitif, } 45 \% \text { dari responden mengalami } \\
\text { perubahan aspek psikomotor dan } 60 \% \text { dari responden mengalami perubahan terhadap } \\
\text { aspek afektif. }\end{array}$ \\
\hline \multicolumn{2}{|r|}{ Abstract } \\
\hline $\begin{array}{l}\text { Keywords: Remote } \\
\text { Learning, PJJ } \\
\text { Impact, PJJ } \\
\text { Constrain }\end{array}$ & $\begin{array}{l}\text { This study was conducted to determine the impact experienced by high school (SMA) } \\
\text { students on cognitive, affective, and psychomotor aspects during distance learning or } \\
\text { online learning. In addition to the perceived impact, there are also obstacles faced by } \\
\text { high school students in the application of distance learning. This research design uses a } \\
\text { qualitative descriptive approach from the results of a questionnaire via google form. } \\
\text { Questionnaires were submitted to high school students starting from class X, XI, and } \\
\text { class XII. The number of respondents in this study were } 20 \text { respondents. The method used } \\
\text { is a qualitative method. From the results of the study that } 80 \% \text { of the respondents took } \\
\text { distance learning and } 20 \% \text { of respondents rarely participated in the distance learning } \\
\text { process. This is experienced by students both majoring in science and social studies. } 50 \% \\
\text { of respondents experienced changes in cognitive aspects, } 45 \% \text { of respondents } \\
\text { experienced changes in psychomotor aspects and } 60 \% \text { of respondents experienced } \\
\text { changes in affective aspects. }\end{array}$ \\
\hline $\begin{array}{l}\text { Diterima/direview } \\
\text { /dipublikasi }\end{array}$ & 11 Juni 2021/13 Juli 2021/30 September 2021 \\
\hline
\end{tabular}

\section{PENDAHULUAN}

Penyebaran covid-19 tidak hanya berpengaruh pada sektor ekonomi, melainkan berpengaruh pula pada dunia pendidikan. Kebijakan physical distancing menjadi dasar adanya kebijakan belajar dari rumah, dengan memanfaatkan teknologi informasi yang mendukung proses pembelajaran dari rumah atau biasa disebut dengan pembelajaran jarak jauh. Transisi dari pembelajaran tatap muka ke pembelajaran jarak jauh atau e-learning (Pembelajaran daring) merupakan bentuk upaya dalam 


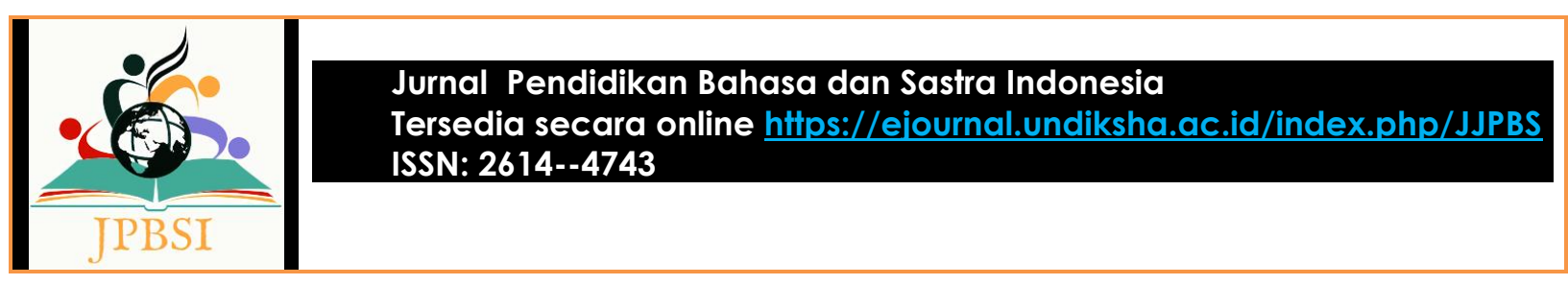

merespon edaran yang ditetapkan oleh Kementerian Pendidikan dan Budaya untuk memutuskan rantai penyebaran covid-19. Transisi dari pembelajaran tatap muka ke pembelajaran jarak jauh tentunya berpengaruh terhadap aspek kognitif, afektif, dan psikomotor.

Perlu kita ketahui terlebih dahulu mengenai belajar, menurut pandangan teori behavioristik belajar adalah perubahan tingkah laku sebagai akibat dari adanya interaksi antara stimulus dan respons. Sedangkan belajar menurut Thorndike, belajar adalah proses interaksi antara stimulus dan respons. Menurut Whittaker (dalam Aunurrahman, 2019) belajar adalah proses di mana tingkah laku ditimbulkan atau diubah melalui latihan atau pengalaman. Menurut Undang-undang Republik Indonesia Nomor 20, tentang sistem pendidikan nasional pembelajaran adalah proses interaksi pendidik dengan peserta didik dan sumber belajar yang berlangsung dalam suatu lingkungan belajar.

Sistem pendidikan di Indonesia menurut Undang-Undang Nomor 20 Tahun 2003 tentang Sistem Pendidikan Nasional, pasal 1 nomor 10 berbunyi satuan pendidikan adalah kelompok layanan pendidikan yang menyelenggarakan pendidikan pada jalur formal, nonformal, dan informal pada setiap jenjang dan jenis pendidikan. Jenjang pendidikan terbagi ke dalam empat jenjang, yaitu anak usia dini, dasar, menengah, dan tinggi. Berdirinya sebuah pendidikan bukan tanpa adanya fungsi dan tujuan. Fungsi dan tujuan pendidikan seperti yang tertuang dalam Undang-Undang nomor 20 tahun 2003 (pasal 3), meyebutkan pendidikan nasional berfungsi mengembangkan kemampuan dan membentuk watak serta peradaban bangsa yang bermartabat dalam rangka mencerdaskan kehidupan bangsa, bertujuan untuk berkembangnya potensi peserta didik agar menjadi manusia yang beriman dan bertakwa kepada Tuhan Yang Maha Esa, berakhlak mulia, sehat, berilmu, cakap, kreatif, mandiri, dan menjadi warga negara yang demokratis serta tanggung jawab.

Pendidikan menjadi ranah utama bagi suatu bangsa untuk mengembangkan atau menjadikan masyarakatnya, khususnya generasi muda menjadi manusia yang berakal, bermoral dan bersosial. Pendidikan menjadi pola atau cara perubahan tingkah laku yang harus terjadi kepada peserta didik. Cara yang harus dilakukan agar perubahan tingkah laku tersebut terwujud dengan melalui proses belajar mengajar. Belajar ialah proses timbal balik antara pendidik dan peserta didik. Selain itu, belajar juga merupakan proses penyampaian informasi atau transfer ilmu dari pendidik kepada peserta didik. Dalam pendidikan formal biasanya dilakukan oleh lembaga yang disebut sekolah atau perguruan tinggi. Masing-masing dari lembaga tersebut menarik siswa atau mahasiswa nya untuk belajar tatap muka di satu titik yang disebut sekolah atau kampus.

Penyebaran covid-19 tidak hanya berpengaruh pada sektor ekonomi, melainkan berpengaruh pula pada dunia pendidikan. Kebijakan physical distancing menjadi dasar adanya kebijakan belajar dari rumah, dengan memanfaatkan teknologi informasi yang mendukung proses pembelajaran dari rumah atau biasa disebut dengan pembelajaran jarak jauh. Transisi dari pembelajaran tatap muka ke pembelajaran jarak jauh atau e-learning (Pembelajaran daring) merupakan bentuk upaya dalam merespon edaran yang ditetapkan oleh Kementerian Pendidikan dan Budaya untuk memutuskan rantai penyebaran covid-19. Transisi dari pembelajaran tatap muka ke pembelajaran jarak jauh tentunya berpengaruh terhadap aspek kognitif, afektif, dan psikomotor.

Pada bulan Maret 2020, pemerintah melalui Menteri Pendidikan dan Kebudayaan mengeluarkan Surat Edaran nomor 36962/MPK.A/HK/2020 tentang Pembelajaran secara Daring dan Bekerja dari Rumah. Surat ini dikeluarkan karena sedang maraknya kasus pandemik Covid-19 yang di derita oleh seluruh negara, termasuk Indonesia. Penyebaran covid-19 di Indonesia semakin meningkat setiap harinya. Hal ini yang membuat pihak kementrian mengeluarkan surat edaran tersebut demi mencegah angka penyebaran covid-19. Setelah surat ini keluar, semua proses akademik dilakukan secara daring, di rumah masing-masing. 


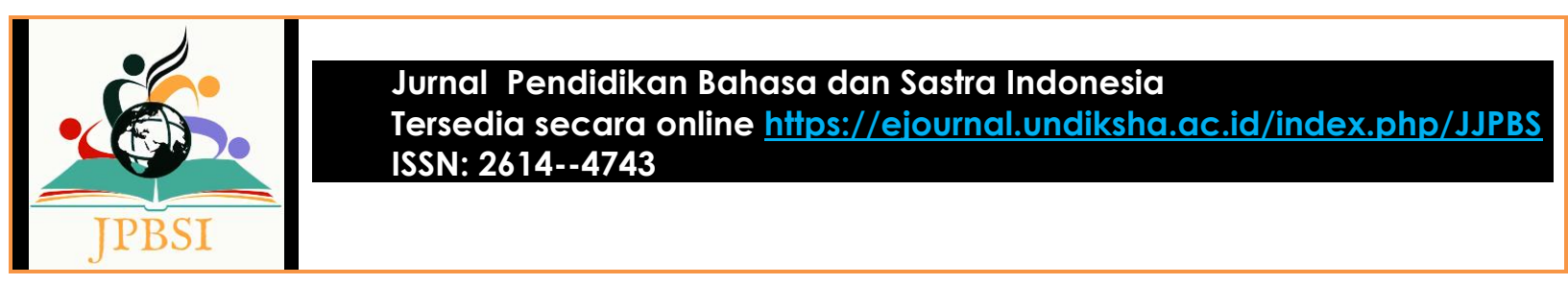

Transisi pembelajaran dari tatap muka ke pembelajaran jarak jauh memang tidaklah mudah. Transisi pembelajaran ini, memang terkesan memaksa berbagai pihak untuk mengikuti alur yang dapat ditempuh agar pembelajaran tetap efektif meski melalui elearning. Pemanfaatan informasi teknologi merupakan solusi utama agar pembelajaran tetap berjalan dan salah satu upaya untuk meningkatkan aspek pendidikan meski dengan kondisi seperti ini. Namun, hal tersebut masih perlu dipertanyakan apakah efektif atau tidak pemberlakuan pembelajaran jarak jauh bagi siswa menengah atas. Penetapan pembelajaran jarak jauh tentunya memiliki banyak kendala dan dampak yang dihadapi oleh siswa menengah atas (SMA).

Salah satu kendala tersebut adalah sinyal di setiap daerah berbeda sehingga menentukan kefektifan proses pembelajaran. Hal ini yang menjadi pro kontra adanya aktivitas pembelajaran jarak jauh. Pembelajaran jarak jauh selain untuk mencegah penyebaran covid-19, menjadi momok yang sangat mengerikan bagi mereka yang berada di garis kemiskinan dan tinggal jauh diluar perkotaan. Tidak semua peserta didik memiliki penunjang pembelajaran jarak jauh ini, tidak semua juga wilayah menjangkau sinyal dengan baik. Penelitian ini bertujuan untuk mengetahui dampak pembelajaran jarak jauh baik positif maupun negatif terhadap aspek kognitif, afektif, dan psikomotor. dan tentunya untuk mengetahui bagaimana pemahaman siswa menengah atas (SMA) setelah diterapkannya pembelajaran jarak jauh.

Menurut Yaumi (dalam Rizkulloh, 2020) pembelajaran jarak jauh adalah suatu pendekatan pembelajaran yang pada pelaksanaannya tidak bertatap muka langsung di kelas. E-learning bisa digunakan dalam kondisi seperti ini, karena berbasis internet yang berarti tidak perlu datang ke kelas. Kemudian menurut Bloom (dalam Supriadi 2019) terdapat teori perkembangan dari tiga domain yaitu kognitif, afektif, dan psikomor. Kognitif merupakan perilaku yang menekankan pada intelektualnya, seperti pengetahuan dan keterampilan berpikir. Afektif lebih menekankan pada aspek perasaan, seperti minat dan sikap. Sedangkan psikomotor lebih menekankan pada keterampilan motorik.

Menurut Bloom (dalam Aunurrahman, 2019) ranah kognitif terdiri dari enam jenis perilaku yaitu pengetahuan, pemahaman, penerapan, analisis, sintesis, dan evaluasi. Ranah afektif terdiri dari lima jenis perilaku yaitu penerimaan, partisipasi, penilaian dan penentuan sikap, organisasi, dan pembentukan pola hidup. Ranah psikomotor menurut Simpon (dalam Aunurrahman, 2019) terdiri dari tujuh perilaku yaitu persepsi, kesiapan, gerakan terbimbing, gerakan terbiasa, gerakan kompleks, penyesuaian pola gerakan, dan kreativitas. Sedangkan menurut Bloom (dalam Supriadi, 2019) domain psikomotor meliputi imitation, manipulation, precision, articulation, naturalization. Ketiga aspek tersebut perlu dikaji karena untuk mengetahui tingkat keberhasilan siswa maupun tenaga pendidik di dalam proses belajar mengajar. Peserta didik atau siswa diharapkan mampu mencapai keberhasilan belajar sesuai dengan jenjang kemampuan di dalam taksonomi tersebut. Keberhasilan siswa di dalam proses pembelajaran merupakan keberhasilan tenaga pendidik di dalam mencapai tujuan pendidikan. Menurut Bloom, dkk (dalam Ruwaida, 2019) mengatakan bahwa tujuan pendidikan harus mengacu kepada tiga ranah domain, yaitu kognitif, afektif, dan psikomotorik.

\section{METODE PENELITIAN}

Berdasarkan jenis penelitian, metode yang digunakan yaitu metode deskriptif kualitatif. Hal ini berdasarkan objek penelitiannya berupa fenomena sebagaimana adanya dari responden mengenai pengaruh dan kendala pembelajaran jarak jauh terhadap aspek kognitif, afektif, dan psikomotor bagi siswa Sekolah Menengah Atas (SMA) di tengah pandemi. Data yang digunakan penelitian ini berupa survei kuesioner yang dibuat melalui google form dengan mengajukan beberapa pertanyaan seputar pembelajaran jarak jauh, aplikasi yang digunakan saat pembelajaran jarak jauh, dan kendala yang dihadapi saat proses pembelajaran jarak jauh. Adapun teknik pengumpulan data, yaitu peneliti mulanya membuat google form kemudian tautan disebarluaskan melalui aplikasi whatsapp kepada salah satu siswa sekolah menengah atas. Subjek penelitian yakni siswa sekolah menengah atas baik 


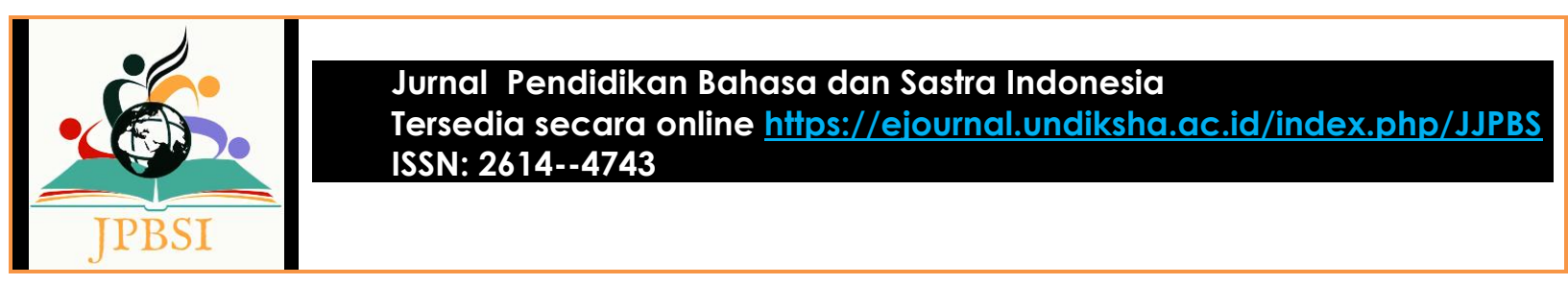

jurusan IPS maupun IPA mulai dari kelas X, XI, dan XII secara acak sebagai sampel. Terdapat 20 siswa yang memberikan tanggapan terhadap survei yang dilakukan peneliti, 11 di antaranya berasal dari jurusan IPS dan 9 di anatarnya siswa jurusan IPA. Dalam penelitian ini jenis data yang dikumpulkan berupa data primer artinya data langsung didapat dari responden yang mengisi tautan google form, sehinnga data yang diperoleh tidak diragukan.Teknik analisis data menggunakan teknik statistik deskriptif. Dengan teknik statistik deskriptif ini, peneliti hanya mendeskripsikan atau menggambarkan data yang telah terkumpul tanpa maksud membuat sebuah kesimpulan.

\section{HASIL DAN PEMBAHASAN}

Pengumpulan data penelitian yang dilakukan peneliti melalui kuesioner. Kuesioner yang dibuat dalam bentuk online atau dengan menggunakan aplikasi google form. Pembuatan kuesioner bertujuan mempermudah peneliti untuk mengukur atau mengetahui sejauh mana keefektipan pembelajaran jarak jauh terhadap tiga domain Taksonomi Bloom. Kuesioner diisi secara daring oleh siswa sekolah menengah atas jurusan IPA dan IPS mulai dari kelas X, XI, dan XII dengan responden sebanyak 20 siswa. Deskripsi responden dapat dilihat pada tabel 1.

Tabel 01. Deskripsi Responden

\begin{tabular}{|c|c|c|c|c|c|c|c|}
\hline \multicolumn{8}{|c|}{ Jumlah Responden } \\
\hline \multirow[b]{2}{*}{ Jurusan } & \multicolumn{3}{|c|}{$I P A$} & \multicolumn{3}{|c|}{$I P S$} & Jumlah \\
\hline & \multicolumn{3}{|c|}{$\begin{array}{c}45 \% \\
9 \text { siswa }\end{array}$} & \multicolumn{3}{|c|}{$\begin{array}{c}55 \% \\
11 \text { siswa }\end{array}$} & $\begin{array}{c}100 \% \\
20 \text { siswa }\end{array}$ \\
\hline Kelas & $X$ & $X I$ & $X I I$ & $X$ & $X I$ & $X I I$ & \\
\hline & 1 siswa & 5 siswa & 3 siswa & 0 siswa & 0 siswa & 11 siswa & 20 siswa \\
\hline
\end{tabular}

Dari Tabel 01 dapat diuraikan bahwa dari 20 responden terdapat sembilan siswa dari jurusan IPA dengan presentase $45 \%$ yakni satu siswa dari kelas X, lima siswa dari kelas XII, dan tiga siswa dari kelas XII. Sedangkan dari jurusan IPS terdapat 11 siswa dengan persentase 55\% yang seluruhnya diisi oleh kelas XII. Dalam pelaksanaanya, dari 20 responden terdapat 16 siswa dengan persentase $80 \%$ yang mengikuti proses pembelajaran jarak jauh dan empat siswa dengan persentase $20 \%$ yang jarang mengikuti proses pembelajran jarak jauh. Dari data sampel tersebut, terdapat sembilan siswa dari jurusan IPA dan tujuh siswa dari jurusan IPS mengikuti proses pembelajaran jarak jauh, serta empat siswa dari jurusan IPS yang jarang mengikuti proses pembelajaran jarak jauh.

Adapun berbagai macam persepsi dari responden mengenai makna pembelajaran jarak jauh, peneliti menyimpulkan bahwa pembelajaran jarak jauh merupakan proses kegiatan belajar mengajar (KBM) formal yang dilakukan secara daring dengan memanfaatkan berbagai macam alat teknologi baik berupa gawai ataupun komputer jinjing. Jadi, pembelajaran jarak jauh ini merupakan proses kegiatan belajar mengajar bukan di sekolah atau lembaga pendidikan lainnya. Pembelajaran ini berlangsung dikediaman masing-masing dengan menggunakan gawai dan komputer jinjing sebagai alat bantu untuk melakukan video conference. Namun, dalam pengaplikasiannya, responden mengeluhkan minimnya kegiatan belajar mengajar tersebut. Pada hakikatnya, kegiatan belajar mengajar merupakan proses stimulus dan respons yang harus dijalani oleh siswa dan guru. Sedangkan, mereka hanya mendapatkan keterbatasan penyampaian materi bahkan ada yang tidak menyampaikan materi sama sekali dan langsung memberikan tugas. Menurut Rambe (2018), peran guru dalam kegiatan belajar mengajar yang efektif, yaitu guru harus mampu membimbing, mengarahkan, memotovasi dan memfasilitasi siswa agar siswa dapat berperan aktif dan mampu mencapai tujuan yang diharapkan.

Untuk melakukan pembelajaran jarak jauh, selain gawai dan komputer jinjing, siswa juga diperlukan mengunduh berbagai macam aplikasi penunjang yang harus ada di dalam gawai atau komputer jinjing tersebut. Aplikasi penunjang ini selain sebagai video conference juga sebagai media 


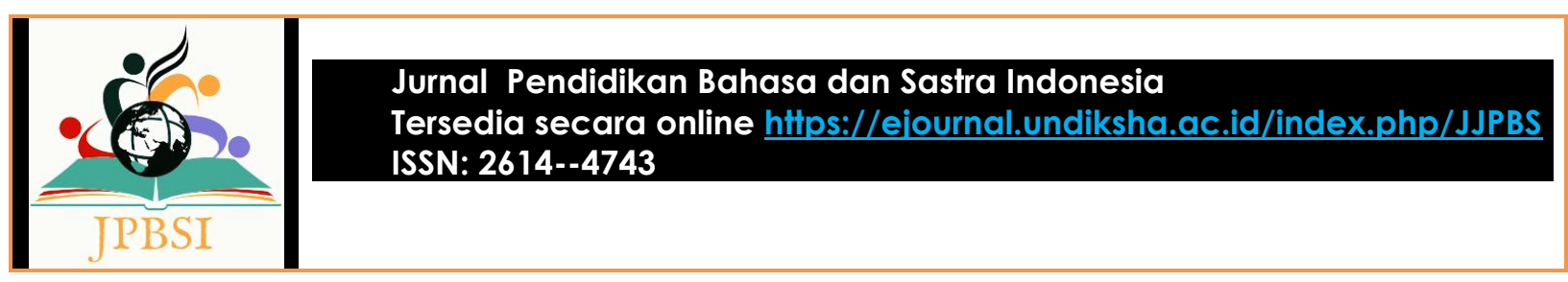

nontonan materi pembelajaran dan sebagai alat komunikasi satu dengan lainnya. Adapun aplikasi penunjang yang digunakan dalam proses pembelajaran jarak jauh tersebut, antara lain Google Classroom, Zoom Meeting, Whatsapp, Telegram, Youtube, Google Form, dan Camscanner. Namun, dalam menggunakan aplikasi tersebut terdapat beberapa kendala yang secara khusus dihadapi oleh siswa ketika proses pembelajaran jarak jauh berlangsung, seperti susah sinyal dan kapasitas kartu memori yang tidak memadai untuk mengunduh berbagai aplikasi tersebut.

Adapun tiga pertanyaan inti yang diajukan peneliti dalam kuesioner, yaitu perihal yang dialami oleh siswa Sekolah Menengah Atas (SMA) terhadap perubahan tiga domain teori Bloom yaitu kognitif, afektif, dan psikomotor. Menurut Huda (dalam Magdalena, dkk, 2020) dalam ranah kognitif mencakup ingatan atau pengenalan terhadap fakta-fakta, pola-pola procedural, serta konsep-konsep yang mempengaruhi berkembanya kemampuan atau skill yang intelektual. Selain ranah kognitif, menurut Degeng (dalam Magdalena, dkk, 2020) yang mencakup ranah afektif yaitu hal yang berkaitan dengan perkembangan perasaan, sikap, nilai, serta emosi. Sedangkan di dalam ranah psikomotor mencakup hal-hal yang berkaitan dengan kegiatan-kegiatan manipulative atau perihal yang berkaitan dengan keterampilan motorik. Pembelajaran yang efektif akan membawa perubahan ke dalam segi positif, termasuk meningkatnya tiga domain taksonomi Bloom ini. Akan tetapi, pembelajaran yang tidak efektif akan membawa kegagalan tujuan belajar sebagai adanya perubahan pada tingkah laku. Hasil kuesioner diuraikan pada tabel 2 sebagai berikut.

Tabel 02 Hasil Kuesioner Perihal Perubahan Tiga Domain Teori Bloom Oleh Responden

\begin{tabular}{|l|l|l|l|l|}
\hline \multicolumn{2}{|c|}{ Perubahan Tiga Domain Teori Bloom } \\
\hline \multirow{2}{*}{ Indikator } & \multicolumn{2}{|c|}{ Ya } & \multicolumn{2}{c|}{ Tidak } \\
\cline { 2 - 5 } & Frekuensi & Persentase & Frekuensi & Persentase \\
\hline Kognitif & 10 siswa & $50 \%$ & 10 siswa & $50 \%$ \\
\hline Afektif & 12 siswa & $60 \%$ & 8 siswa & $40 \%$ \\
\hline Psikomotor & 9 siswa & $45 \%$ & 11 siswa & $55 \%$ \\
\hline
\end{tabular}

Dari Tabel 02 dapat diuraikan bahwa dalam pembelajaran jarak jauh ternyata berpengaruh terhadap ranah taksonomi Bloom. Dari segi ranah kognitif terdapat 50\% dari siswa yang mengalami perubahan secara pengetahuan dan $50 \%$ tidak ada perubahan sama sekali. Perubahan yang didapat, yaitu siswa mulai terbiasa mencari dan mempelajari materi secara mandiri serta siswa mampu memahami materi yang tadinya belum diketahui menjadi diketahui. Kedua, dari segi ranah afektif, terdapat $60 \%$ dari siswa yang mengalami perubahan dan $40 \%$ dari siswa yang tidak sama sekali mengalami perubahan. Perubahan tersebut berupa peningkatan indisipliner yang terjadi kepada siswa, seperti masuk kelas daring tepat waktu dan lebih rajin untuk mengamati serta memahami materi karena terdapat pengurangan waktu kegiatan belajar mengajar dari pihak sekolah. Ketiga, dari segi ranah psikomotor terdapat $45 \%$ siswa yang mengalami perubahan secara skill atau kemampuan dan $55 \%$ tidak ada perubahan. Perubahan yang dialami dari ranah psikomotor, yaitu siswa lebih memahami IPTEK dan mampu mengaplikasikannya. Selain perubahan yang dialami oleh siswa dari aspek kognitif, afektif, dan psikomotor siswa Sekolah Menengah Atas (SMA) pun merasakan dampak positif selama pembelajaran jarak jauh di tengah pandemi diberlakukan. Dampak positif yang dirasakan siswa yaitu seperti mampu menyelesaikan soal yang ada di Lembar Kerja Siswa (LKS) secara tenang, dapat mengikuti kegitan di luar kegiatan sekolah seperti mengikuti webinar dan menjadi relawan, serta siswa lebih menghargai waktu.

Selain dampak positif yang dirasakan, siswa pun merasakan dampak negatif, yaitu kesehatan mata terganggu, kurang beraktivitas, nilai menjadi rendah, serta nilai kejujuran yang ada pada siswa berkurang misalnya saat siswa mengerjakan soal ujian, siswa lebih mudah mencontek. Hal tersebut terjadi karena kurangnya pengawasan dari guru. Mayoritas siswa Sekolah Menengah Atas lebih menyukai pembelajaran secara tatap muka karena pelaksanaan pembelajaran jarak jauh kurang 


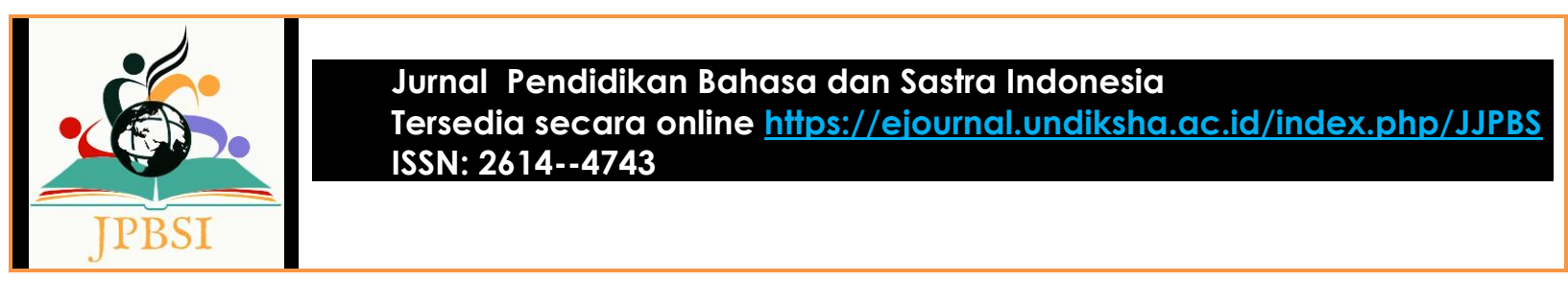

efektif. Selain pembelajarannya yang kurang efektif, tingkat pemahaman siswa Sekolah Menengah Atas terhadap materi yang disampaikan oleh guru menurun.

Menjadi seorang guru di tengah pandemi memang tidak mudah. Oleh karena itu, sebagai seorang pendidik harus terbuka dengan ilmu teknologi. Seorang pendidik juga harus kreatif dan inovatif terutama di dalam pembuatan media pembelajaran. Media pembelajaran yang menarik dapat memotivasi minat belajar siswa agar lebih baik. Selain itu, pendidik juga harus mampu memposisikan dirinya dengan siswa sebagai teman, mau banyak belajar, mau berusaha untuk konsisten, dan mengajar dengan sepenuh hati.

\section{PENUTUP}

Dari data yang peneliti dapat, 50\% siswa mengalami perubahan secara kognitif, sisanya tidak mengalami perubahan sama sekali. Perubahan tersebut antara lain, siswa terbiasa dengan mencari informasi materi sendiri dan tetap mendapatkan ilmu yang tidak diketahui menjadi diketahui. Kedua, $60 \%$ dari siswa yang mengalami perubahan dalam aspek afektif dan $40 \%$ dari siswa yang tidak sama sekali mengalami perubahan. Perubahan tersebut berupa peningkatan indisipliner yang terjadi kepada siswa, seperti masuk kelas daring tepat waktu dan lebih rajin untuk mengamati serta memahami materi karena terdapat pengurangan waktu kegiatan belajar mengajar dari pihak sekolah. Ketiga, dari segi ranah psikomotor terdapat $45 \%$ siswa yang mengalami perubahan secara skill atau kemampuan dan 55\% tidak ada perubahan. Perubahan yang dialami dari ranah psikomotor, yaitu siswa lebih memahami IPTEK dan mampu mengaplikasikannya.

\section{DAFTAR PUSTAKA}

Aunurrahman. 2019. Belajar dan Pembelajaran. Bandung: Alfabeta.

Supriadi, Oding. 2019. Perkembangan Peserta Didik. Yogyakarta: Kurnia Kalam Semesta.

Rizkulloh, Ridho. 2020. Artikel Review Tentang E-learning dan Pembelajaran Jarak Jauh Saat Masa Pandemi. Jurnal Research. (Online). Tersedia: http://www.researchgate.net/publication. (05 Desember 2020).

Ruwaida, Hikmatu. 2019. Proses Kognitif Dalam Taksonomi Bloom Revisi: Analisis Kemampuan Mencipta (C6) Pada Pembelajaran Fikih Di Mi Miftahul Anwar Desa Banua Lawas: AlMadrasah:Jurnal Ilmiah Pendidikan Madrasah Ibtidaiyah, 4(1), hlm. 5.

Rambe, Riris Nur Kholidah. 2018. Penerapan Strategi Index Card Match Untuk Meningkatkan Hasil Belajar Siswa Pada Mata Pelajaran Bahasa Indonesia. Jurnal Tarbiyah, Vol. 25, No. 1. Tersedia: http://www. http://jurnaltarbiyah.uinsu.ac.id/. (04 Juli 2021).

Magdalena, Ina dkk. 2020. Tiga Ranah Taksonomi Bloom dalam Pendidikan. Jurnal STITPN, Vol. 2, No.1. Tersedia: http://ejournal.stitpn.ac.id. (04 Juli 2021).

Copyright holder: ๑ Meilani, L., Bastulbar, B. \& Pratiwi, W. D.(2021)

Fist publication right: Jurnal Pendidikan Bahasa dan Sastra Indonesia Undiksha

(c) (i) (2) 